\title{
Optimising Selenium for Modulation of Cancer Treatments
}

\author{
STEPHEN OWEN EVANS ${ }^{1 *}$, PUTERI FARISA KHAIRUDDIN ${ }^{2 *}$ and MICHAEL B. JAMESON ${ }^{2}$ \\ ${ }^{1}$ Biomedical Research Unit, School of Science, University of Waikato, Hamilton, New Zealand; \\ ${ }^{2}$ Department of Oncology, Waikato Hospital, Hamilton, New Zealand
}

\begin{abstract}
Selenium is an essential trace element involved in many biological processes that are mediated through, at least, 25 selenoproteins expressed in humans. Extensive study of selenium compounds has demonstrated growth inhibition of malignant cells in a vast array of experimental models. Moreover combining selenium with conventional cancer therapy has yielded promising results in both preclinical studies and a cohort of human trials. The aim of this review is to highlight the current research evaluating the role of selenium compounds in combination with chemotherapy and radiation. Pharmacodymanic mechanisms responsible for the differential effects of the commonly studied compounds on healthy and malignant cells are presented and the pertinent in vitro and in vivo data summarised. The clinical utility of this approach is discussed both in terms of anti-tumour efficacy and toxicity prevention. Finally a case is made for novel trial designs to facilitate rapid progression into pivotal studies.
\end{abstract}

Selenium ( $\mathrm{Se}$ ) is one of the most extensively studied trace elements, especially with regard to cancer. Most of this research relates to nutritional doses of Se in healthy people as primary prevention of cancer, with strong evidence that populations with low Se intakes are at higher risk of cancer (1-3); in these groups, supplementation may reduce cancer incidence and cancer-specific mortality (4). However it appears that there can be "too much of a good thing" with

This Article is freely accessible online.

*These Authors contributed equally to this study.

Correspondence to: Michael B Jameson, Department of Oncology, Waikato Hospital, Private Bag 3200, Hamilton 3240, New Zealand. E-mail: Michael.jameson@waikatodhb.heath.nz

Key Words: Selenium, cancer, radiotherapy, chemotherapy, toxicity and efficacy, review.
Se; not only does supplementing with supranutritional doses of Se in Se-replete populations not confer protection against cancer (5), laboratory and clinical studies suggest this may even increase the risk of cancer $(6,7)$.

Many patients extrapolate the prevention data and take Se (often at supranutritional doses) to try and control their existing cancer $(8,9)$. There is very little clinical research relevant to this practice but one study on prostate cancer showed no restraint of prostate-specific antigen (PSA) velocity and, of greater concern, in those with the highest baseline serum Se, supplementation with $800 \mu \mathrm{g}$ daily of selenized yeast actually significantly increased PSA velocity (10).

While this generates concern about patients using Se as a sole treatment for cancer, especially in those who have adequate $\mathrm{Se}$ intakes, there is substantial preclinical research and some early clinical trials suggesting that Se compounds may significantly protect against the normal tissue toxicities of cancer therapies without compromising their anticancer efficacy (or even enhancing it) (11-13). The mechanisms that mediate this are being increasingly explored and understood and, in contrast to primary prevention, the beneficial interactions of Se with cancer treatments appear to be dosedependent, with maximum efficacy at doses much greater than nutritional requirements (13).

While this is encouraging, considerable uncertainties slow the progress of research in this area. It is not clear what chemical form of $\mathrm{Se}$ is most effective, nor at what dose (which has varied from $<100$ to $90,000 \mu \mathrm{g} /$ day). While the $\mathrm{Se}$ dose has sometimes been guided by preclinical pharmacokinetic (PK) studies, there has not been a clear evaluation of the pharmacokinetic-pharmacodynamic (PKPD) relationship for various Se compounds, nor comparison of their differential effects on normal and malignant cells at different concentrations for each compound. Furthermore the toxicities of supranutritional doses of the different $\mathrm{Se}$ compounds in clinical use have not been systematically evaluated. Of particular concern is the genotoxicity of some forms of Se, particularly the inorganic salts (14), and the possibility that using these in conjunction with other 
genotoxic therapies (such as radiation and alkylating agents) could increase the risk of second malignancies and myelodysplasia. No clinical trials to date have reported on such end-points.

This review focuses on the preclinical and clinical evaluation of the interaction of $\mathrm{Se}$ compounds with chemotherapy and radiation, the PK-PD relationship of these compounds and differential effects and thresholds in normal and malignant cells. Ultimately we wish to use this information to inform the rational development of further clinical trials that can definitively assess whether these Se compounds can meaningfully reduce the burden of toxicities of cancer treatments for patients while maintaining or improving their efficacy, as suggested by preclinical studies.

\section{Selenium - Role in Human Health}

It is well known that Se intake varies hugely worldwide due to differences in diet and soil content of Se in different geographical locations. Although a recommended dietary intake of Se has been established, it is difficult to give a broad recommendation for a specific dose (6). 'Nutritional' doses ranging from 50-200 $\mu \mathrm{g} /$ day have been used mainly for primary prevention (15), and Se supplementation at these doses for Se-deplete individuals has been associated with lower overall mortality and incidence of certain cancer types (6). However, as alluded to earlier, it is well known that taking Se at supranutritional doses over a long duration can cause adverse effects, a reminder that $\mathrm{Se}$ is also recognised as a toxic element (6).

The role of Se in maintaining health is complex and it has many important biological functions including in redox signalling, thyroid metabolism, immune function, detoxification and antioxidant activity (6). These effects are primarily mediated by over 25 specific encoded selenoproteins, in which selenocysteine replaces cysteine. Among the more widely studied selenoproteins are the glutathione peroxidases (involved in antioxidant activity and sperm motility) and thioredoxin reductases (involved in intracellular redox regulation and signalling). The pronounced immunostimulant effects of Se can cause a wide array of effects, from increased proliferation of activated T-cells and natural killer cell activity to enhanced lymphocyte-mediated tumour cytotoxicity (6).

\section{Selenium Compounds - Metabolism, Pharmacology and Toxicity}

Se exists in different chemical forms and these compounds can be broadly categorized into organic and inorganic forms. The metabolic pathway of dietary Se is shown in Figure 1.

There is good evidence that the increased Se status attained after supplementation with organic forms of Se such as Semethyl-selenocysteine (MSC) and L-selenomethionine (SLM), is maintained for a longer period after its discontinuation compared to inorganic forms such as sodium selenate reported whole-body half-lives of SLM and sodium selenate in humans were 252 and 102 days respectively (16). Accordingly, foods or supplements containing SLM can maintain the activities of selenoenzymes during periods of Se depletion for longer than those containing inorganic Se, owing to the recycling of SLM catabolised from protein stores.

Animal laboratory studies have shown that the organic forms of Se are both more effective and safer than the commonly-used inorganic forms such as sodium selenite (SS), which are more genotoxic (14). From 50\% lethal dose $\left(\mathrm{LD}_{50}\right)$ determinations, SS was found to be fourfold more toxic than SLM when administered to mice intravenously and three-fold more toxic than Se-yeast when given orally to rats (17).

In humans safety data is more limited. The No Observed Adverse Effect Level (NOAEL) for Se in humans is variably reported as $400-850 \mu \mathrm{g} /$ day $(18,19)$. Chronic Se toxicity would be expected after long-term consumption (over months to years) of more than 2,400-3,000 $\mu \mathrm{g}$ /day but is reversible (20). Based on the published literature, likely symptoms of toxicity (due to environmental exposure) include brittle hair and nails and their loss, gastrointestinal disturbances, skin rash, garlic breath odour (caused by volatile selenium compounds) fatigue, irritability, and nervous system abnormalities. Impaired natural killer cell activity and endocrine disturbances may also occur (20).

Three major forms of Se (MSC, SLM and SS) are widely used in supplementation in both preclinical and clinical studies. The organic Se compound MSC is a water-soluble amino acid that is absorbed in mammals from the gastrointestinal tract and is well-tolerated (21). It is readily converted to the active moiety methylselenol through onestage $\beta$-lyase conversion and remains more bioavailable for anticancer effects compared with the other forms (22). Methylselenol can be demethylated to yield selenide or methylated to yield dimethyl selenide, then released in the breath; methylated again, it yields trimethyl selenonium, which is excreted in urine (23). A phase 1, single-dose, doseescalation study in 15 human subjects evaluated the toxicity and PK profile of MSC, administering 400, 800 and 1,200 $\mu \mathrm{g}$ of MSC orally and measuring Se plasma and urine levels. There was no significant clinical or laboratory toxicity and little difference was seen in PK parameters at the 400 and $800 \mu \mathrm{g}$ dose levels (23).

The organic Se compound SLM is well-tolerated in humans at a dose of 7,200 $\mu \mathrm{g}$ (or comparable dosing at 3,600 $\mu \mathrm{g} / \mathrm{m}^{2}$ ) twice daily for 7 days followed by a once-daily maintenance dose for 10 weeks $(24,25)$. The only toxicity attribute to SLM was garlic-like odour in breath and urine that was seen more commonly during the induction SLM week and was found to disappear with prolonged treatment. All patients given 4,800 $\mu \mathrm{g}$ 


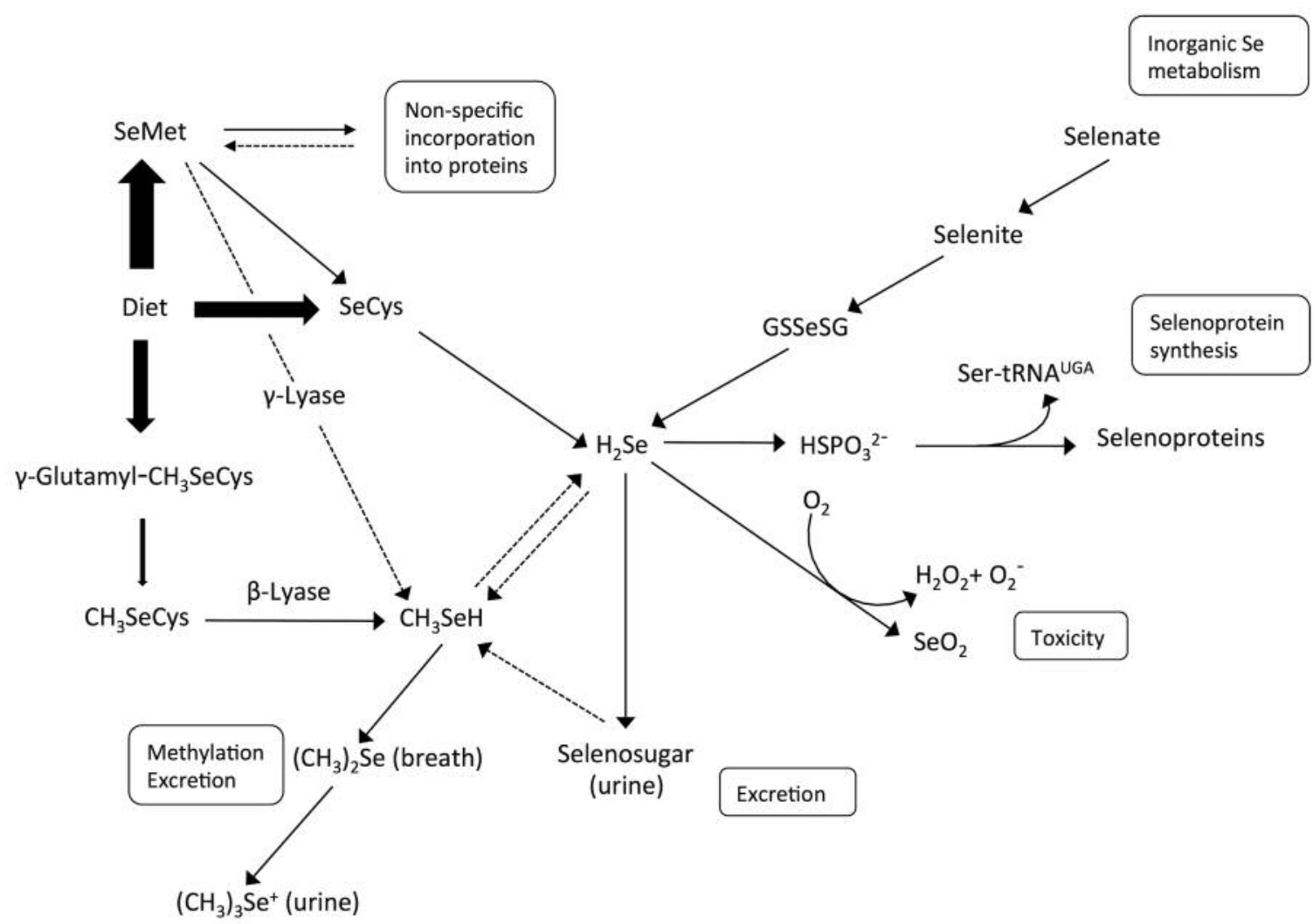

Figure 1. Metabolic pathway of dietary Se in humans, from Rayman et al. (93). SeMet, Selenomethionine; SeCys, selenocysteine; GSSeSG, selenodiglutathione; $\gamma$-glutamyl- $\mathrm{CH}_{3} \mathrm{SeCys}, \gamma$-glutamyl-Se-methyl-selenocysteine; $\mathrm{H}_{2} \mathrm{Se}$, hydrogen selenide; $\mathrm{HSePO}_{3}$, selenophosphate; $\mathrm{CH}_{3} \mathrm{SeCys}$, Se-methylselenocysteine; $\mathrm{CH}_{3} \mathrm{SeH}$, methylselenol; $\left(\mathrm{CH}_{3}\right) 2 \mathrm{Se}$, dimethyl selenide; $\mathrm{SeO}_{2}$, selenium dioxide; $\left(\mathrm{CH}_{3}\right) 3 \mathrm{Se}$, trimethylselenonium ion.

SLM twice daily achieved plasma Se levels $>15 \mu \mathrm{M}$, the Se concentration required for reduced chemotherapy-induced toxicity and enhanced antitumor efficacy of chemotherapeutic drugs in preclinical animal models (13). The plasma Se dose levels exceeded $30 \mu \mathrm{M}$ by day 28 , thereby confirming the feasibility of using high-dose SLM in the clinic in this setting. In another study, selenized yeast (which predominantly contains SLM) was given in doses of $3,200 \mu \mathrm{g}$ daily for up to 24 months in 16 patients with prostate cancer on 'watchful waiting', with five patients reporting minor toxicities, including garlic breath, brittle nails or hair, stomach upset or dizziness, without any correlation with plasma Se levels (18). None of these patients reported symptoms of peripheral neuropathy.

The inorganic compound sodium selenate (which is metabolised to selenite) was evaluated in a recent phase I trial, which established a maximum tolerated dose (MTD) of $60,000 \mu \mathrm{g}$ daily orally in patients with metastatic castrationresistant prostate cancer (26). Dose-limiting toxicities of fatigue and diarrhoea were seen at $90,000 \mu \mathrm{g}$, with adverse events including nail disorders, muscle spasms, alopecia and nausea. Some of these were attributed to the accumulation of selenite, the more potent metabolite of selenate. In the same trial, slowing of PSA velocity was also observed, and one patient had $>50 \%$ reduction in serum PSA. Another clinical trial adding SS $200 \mu \mathrm{g} / \mathrm{kg} /$ day (equivalent to $14,000 \mu \mathrm{g} / \mathrm{day}$ in a $70-\mathrm{kg}$ adult) to chemotherapy in lymphoma patients reported less toxicity with combination therapy than with chemotherapy alone, including infections and reduction in cardiac function (27).

\section{Pharmacodynamics of Selenium Compounds in Normal and Malignant Cells}

Se affects varied cellular processes and molecular pathways that may be involved in the anti-cancer effect of $\mathrm{Se}$ [reviewed in (3)] and include:

- Seleno-enzymes involving the reduction of DNA damage, oxidative stress and inflammation;

- Induction of phase II conjugating enzymes involving detoxifying carcinogens and reducing DNA adduct formation;

- Enhancement of immune response including cytotoxic lymphocyte and natural killer cell activity; 
- Increase in tumour-suppressor protein p53, which inhibits proliferation, stimulates DNA repair and promoting apoptotic death by acting as a transcription factor for several genes, including the growth arrest and DNA damage-inducible (GADD) genes;

- Inactivation of protein kinase $\mathrm{C}$, a signalling receptor that plays a crucial role in tumour promotion by oxidants;

- Alteration in DNA methylation, as abnormal methylation patterns are associated with neoplasia and inactivation of tumour-suppressor genes;

- Perturbation of the cell cycle, resulting in growth inhibition and may allow DNA repair to take place;

- Induction of apoptosis of cancer cells, which generally involves the sequential activation of the caspases;

- Inhibition of angiogenesis required for the growth and metastasis of tumours.

Reassuringly, there is a significant body of published work demonstrating differential effects of Se compounds in normal versus malignant cells or tissues that would be favourable clinically, as summarised in Table I. However, while there is clear evidence from preclinical work that the efficacy and toxicity of Se compounds varies greatly $(11,14)$, European clinical trials mostly use SS and those in the US use SLM, with no direct comparison of Se compounds or their PK-PD dose relationship.

\section{Selenium with Chemotherapy and Radiotherapy}

The challenge in using Se compounds in cancer patients in conjunction with chemotherapy and/or radiotherapy lies in being able to reduce normal tissue toxicities of these treatments without compromising their antitumour effects (or preferably enhancing those). However, despite numerous studies on the PD of Se in normal and malignant cells, it is still not known which form and dose of Se can be safely used and has the most favourable differential effect in normal and malignant tissues, especially in conjunction with chemotherapy and radiation. Current doses of Se are empirical or guided by PK, although the PK-PD relationship has not been established in humans, hence the optimal form and dose of Se to be used with chemotherapy or radiotherapy remains unclear. However Joel et al. have demonstrated that PD biomarkers of Se effects can be measured in human white blood cells (WBC) in vitro and in vivo (28), thus enabling the relationship between Se PD and PK to be evaluated in clinical studies and determine the optimal Se compound and dose to be incorporated into potentially pivotal trials.

\section{Antitumour Efficacy}

While Se is selectively cytotoxic to cancer cells at higher doses (summarised in Table I), it commonly augments the anticancer efficacy of chemotherapy and radiation in cell culture and tumour xenograft models (summarised in Table II). Therapeutic synergy has been demonstrated between supranutritional doses of Se compounds and chemotherapy drugs, including cisplatin, carboplatin, oxaliplatin, irinotecan, docetaxel, fluorouracil and doxorubicin in human tumour xenografts of colorectal, ovarian, prostate and small cell and non-small cell lung carcinoma, head and neck squamous cell carcinoma and leukaemia $(11,13,29-32)$.

However the strength of the interaction varied greatly, with differing xenograft models showing up to a 20 -fold difference in Se dose potency) (11). Furthermore, the xenograft model and Se dose also influenced the apparent efficacy of the Se compounds. For example, at their MTD of $200 \mu \mathrm{g} /$ day orally (approximately $8,000 \mu \mathrm{g} / \mathrm{kg} / \mathrm{day}$ ), MSC and SLM were both superior to SS in combination with irinotecan in head and neck squamous cell carcinoma xenografts (Figure 2) (11) whereas SS and SLM $(1,000-1,500 \mu \mathrm{g} / \mathrm{kg} /$ day i.p. $)$ were equally dose-potent and effective when combined with cisplatin in an ovarian cancer xenograft model (32).

Attention is also drawn to the schedule-dependency of Se in combination with other cancer treatments: the effects of MSC or SLM were maximal after 7 days pre-treatment, with little or no benefit seen when co-administered without preincubation with Se in human colorectal and head and neck squamous cell carcinoma xenograft models in mice $(11,33)$.

Few clinical studies have been conducted that evaluated the impact of Se supplementation during chemotherapy or radiation on treatment efficacy. Muecke et al. randomised 81 Se-deficient women to oral SS $(500 \mu \mathrm{g}$ daily with radiotherapy and $300 \mu \mathrm{g}$ on non-radiotherapy days) or radiotherapy alone following surgery for gynaecological malignancies (34). At a median follow-up of 67 months, disease-free survival was not significantly different (log-rank $p=0.65)$, though there was there a trend for improved overall survival in the selenium-treated group (log-rank $p=0.09$ ) (35).

Mix et al. conducted a randomised, placebo-controlled phase 2 pilot study in 18 patients with locally-advanced head and neck squamous cell carcinoma receiving cisplatin concurrently with radiation, administering placebo or $3,600 \mu \mathrm{g} / \mathrm{m}^{2}$ SLM twice daily orally for 7 days prior to treatment then once daily until 3 weeks after chemoradiation completion. In this small study, there was no difference observed in disease-free or overall survival (log-rank $p=0.39$ and $p=0.39$ respectively) (24).

Asfour et al. reported a trial randomising 50 patients with non-Hodgkin lymphoma to either very high doses of SS (200 $\mu \mathrm{g} / \mathrm{kg} /$ day) with cyclophosphamide, vincristine, doxorubicin and prednisone chemotherapy or chemotherapy alone (27). A significantly greater tumour response rate was observed in the Se group than controls $(60 \%$ vs. $40 \%$ respectively), with correspondingly lower levels of the oncogene B-cell lymphoma 2 (BCL2) in bone marrow aspirates in Se-treated patients compared to controls. 
Table I. Pharmacodynamic mechanisms of selenium supplementation in normal and malignant cells.

\begin{tabular}{llll}
\hline Pharmacodynamic properties & Effects in normal cells (Ref) & Effects in malignant cells (Ref) & Therapeutic \\
significance
\end{tabular}

Antioxidant effects

Glutathione peroxidase (GPx)

Intracellular glutathione (GSH)

Thioredoxin reductase $(\operatorname{TrxR})$

Cell death/cytotoxicity

DNA repair

Angiogenesis

In human umbilical vein endothelial cells MSA induced apoptosis via p38 MAPK activation whereas SS induced MSA inhibited VEGF expression in

Invasion/migration

Epigenetic

Immunological

Drug efflux caspase-independent apoptosis (64) mammary endothelial cells (65)

Se-dependent GPx isoforms $1,2,3,4$ and 6 reduce oxidative damage; activity saturates with nutritional doses of $\mathrm{Se}(6)$ Increased GSH in PBMCs in response to MSA (50)

Essential selenoprotein (51), increased TrxR activity in red blood cells with selenized yeast (52)

Minimal effects on normal cells $(50,51,55)$

Enhanced DNA repair with SLM in p53 wild-type mouse and human fibroblasts $(60,61)$

$1 \mathrm{mg} / \mathrm{kg}$ SS for 8 weeks increased antigen-specific CD4+ $\mathrm{T}$-cell responses (75)
Increased GPx 1 activity in response to low dose Se (as SS and SLM) in LNCaP cells, resulting in reduced oxidative damage (49)

MSA reduced total GSH in leukaemia cells (50)

Favourable

At low dose SS and SLM increased TrxR activity and apoptosis in LNCaP cells (prostate adenocarcinoma) (49) as did SS in NSCLC cells (53), more so in doxorubicin-resistant compared to doxorubicinsensitive NSCLC cells (54) Higher concentrations of SS reduced TrxR activity in mesothelioma (55), colorectal cancer (56) and NSCLC (53). Differential effect with increase in TrxR activity and protein in doxorubicin-sensitive NSCLC but the opposite in doxorubicin-resistant NSCLC cells (54)

Marked toxicity and cell death in varied malignant cell lines with dose-dependent and Se species-specific mechanisms of cell death or cell cycle arrest [reviewed in (57)]

e.g. comparison of MSC, SS and SLM across multiple cancer cell lines showed:

i) SLM-induced apoptosis is p53-dependent;

ii) MSC instead induced p53-independent caspase activation;

iii) ER stress-related signaling was associated with both SS and MSC (58)

MSA-induced ER stress provoked a survival response at lower doses and apoptosis at higher doses in prostate cancer cell lines (59)

Increase in base excision repair in colorectal cancer lines by SLM is p53 wild type-dependent (62) Unaltered DNA repair in SLM-treated p53-null human squamous cell carcinoma cell lines (63) Low dose SS or SLM increased DNA repair in prostate cancer cell lines (49)

MSC and MSA reduced HIF- $1 \alpha$ expression and thus angiogenesis in HNSCC and renal cell carcinoma models through inhibition of VEGF signaling mediated by COX-2, iNOS and degradation of prolyl hydroxylases under hypoxia (66-69).

This resulted in improved intratumoral vessel maturation, Favourable interstitial fluid pressure and reduced hypoxia (70) Reduced cell invasion through inhibiting MMP-2, MMP-9 and UPA by MSA (71) and SS (72)

Inhibits DNMT and HDAC resulting in expression of silenced genes by SS (73) and MSA (74)

Mixed

Favourable

Mixed

Favourable

Favourable

Favourable

Significant reduction in levels of the ABCC1 efflux pump in tumour cells (76).
Favourable

ABCC1: ATP binding cassette C1; COX-2: cyclooxygenase 2; DNMT: DNA methyltransferase; ER: endoplasmic reticulum; GPx: glutathione peroxidase; GSH: glutathione; HDAC: histone deacetylase; HDSCC head and neck squamous cell carcinoma; HIF-1 $\alpha$ : hypoxia-inducible factor 1 alpha; iNOS: inducible nitric oxide synthase; MAPK: mitogen activated protein kinase; MMP: matrix metalloproteases; MSA: methylseleninic acid; MSC: Semethylselenocysteine; NSCLC: non-small cell lung cancer; p53: tumour protein p53; PBMCs: peripheral blood mononuclear cells; Se: selenium; SLM: seleno-L-methionine; SS: sodium selenite; TrxR: thioredoxin reductase; UPA: urokinase plasminogen activator; VEGF: vascular endothelial growth factor. 

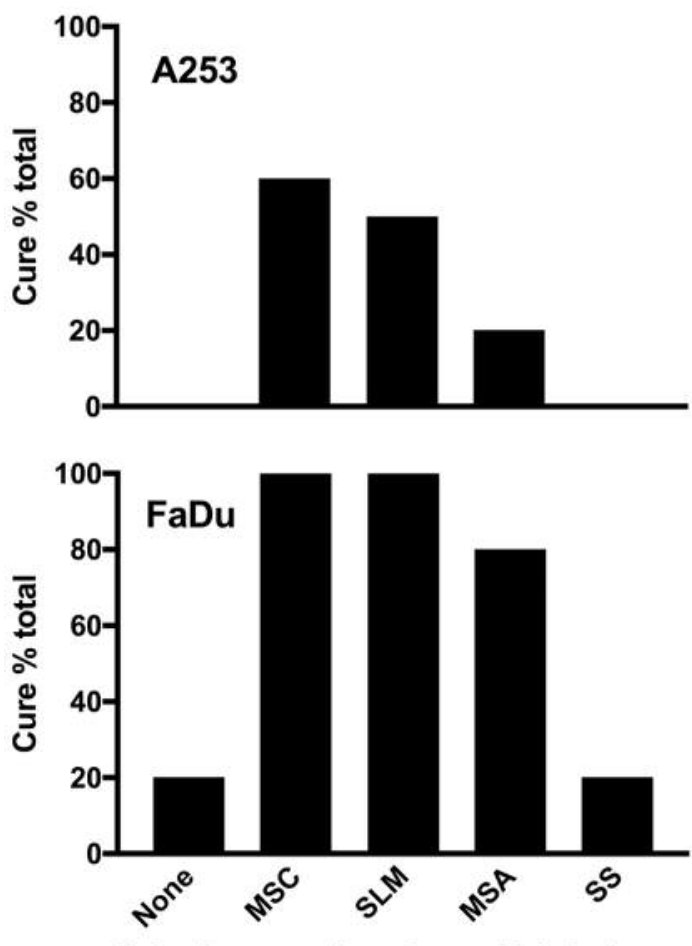

Selenium species given with irinotecan

Figure 2. Tumour cure rates in nude mice with head and neck squamous cell carcinoma xenografts (5 mice per group). Se compounds differ in their ability to improve antitumour activity of irinotecan in xenografts. MSC: Se-Methyl-selenocysteine; SLM: seleno-methionine; MSA: methyl-seleninic acid; SS: sodium selenite. (group means reported) Courtesy of Dr Y Rustum.

\section{Reduction in Toxicity}

Table II summarises extensive preclinical work that demonstrated the protective effects of various Se compounds against the toxicities of radiation $(12,36)$ and organ-specific toxicities of many cytotoxic drugs, including myelosuppression, mucositis, diarrhoea, alopecia, cystitis and nephrotoxicity $(11,13,30,37)$. Specific toxicities of cisplatin in kidneys, bone marrow and intestine were improved without affecting antitumour efficacy $(30,38-41)$ or pharmacokinetics (42). Impressive protection from lethal effects of six cytotoxic drugs with $200 \mu \mathrm{g}$ /day MSC was demonstrated in nude mice (13).

Similar protection by Se compounds from the normal tissue toxicities of chemotherapy has been reported in several clinical trials (Table III). In the setting of high-dose chemotherapy and allogeneic haematopoietic stem cell transplantation, a double-blind randomised placebocontrolled study of oral selenized yeast in 77 patients reported a reduction in the incidence and duration of severe

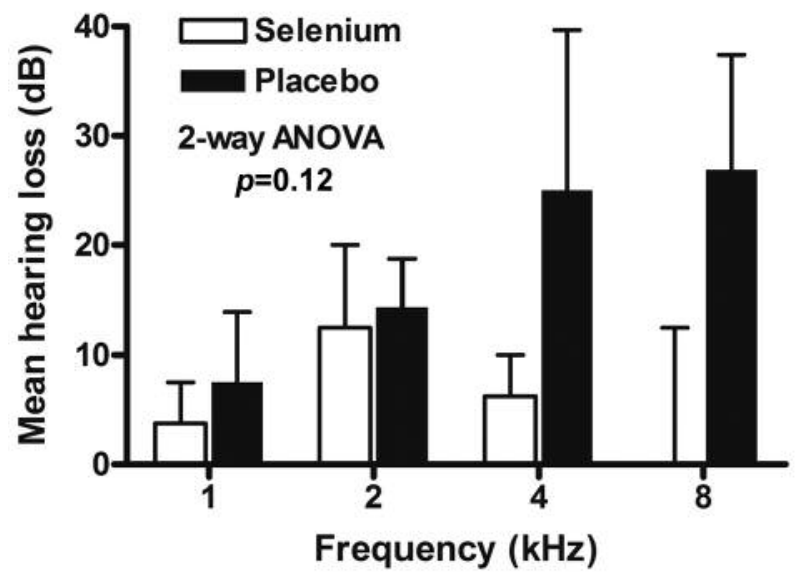

Figure 3. Hearing loss following chemoradiation in selenium-, and placebo-treated groups. $(n=6,2$ Selenium treated, 4 placebo, mean \pm SEM) Courtesy of M. Jameson.

oral mucositis (43). In a trial randomising 41 patients to 4,000 $\mu \mathrm{g}$ Se (as seleno-kappacarrageenan) orally daily for 4 days before and after the first dose of cisplatin-based chemotherapy or to chemotherapy alone, significantly less myelosuppression and nephrotoxicity was seen with Se (44). A double-blind trial involving 62 women receiving cisplatinbased chemotherapy for ovarian cancer randomized patients to Se as selenized yeast, $200 \mu \mathrm{g}$ per day for 3 months, starting concurrently with chemotherapy (45). Those patients randomized to Se experienced significantly less toxicity at 3 months of treatment, including gastrointestinal, alopecia, weakness and neutropenia. The previously referenced four studies using high-dose SS in patients with non-Hodgkin lymphoma reported the Se group had significantly fewer toxicities (including infection and fall in cardiac left ventricular ejection fraction) and reduced apoptosis of neutrophils (46).

Data from the aforementioned study conducted by Muecke et al. reported significantly increased blood Se with SS supplementation (the primary endpoint) but analysis of secondary endpoints showed a significant reduction in the actuarial incidence of grade 2 or more diarrhoea (from $46.6 \%$ to $21.0 \%, p=0.039$ ), without any Se-related sideeffects (12). SS has also been assessed as a potential modulator of radiation-related toxicities in 39 head and neck cancer patients in a randomised controlled trial (36). Using the same dosing schedule of SS as the study of Muecke et al. (12), there was no statistically significant difference in the incidence of severe toxicities.

More recently SLM has been trialled alongside cisplatinbased chemoradiation for both head and neck squamous cell cancer and non-small cell lung cancer (NSCLC), with 
Table II. Combination of selenium with systemic therapies and radiation.

\begin{tabular}{|c|c|c|c|}
\hline Pharmacodynamic properties & Effects in normal cells/tissues (Ref) & Effects in malignant cells/tissues (Ref) & $\begin{array}{l}\text { Therapeutic } \\
\text { significance }\end{array}$ \\
\hline $\begin{array}{l}\text { Antioxidant effects - } \\
\text { Intracellular glutathione } \\
(\mathrm{GSH})\end{array}$ & $\begin{array}{l}\text { Protective increase in GSH in PBMCs in } \\
\text { response to MSA, not compromised by } \\
\text { combination with cisplatin, doxorubicin, } \\
\text { Ara-C or radiation } 2 \text { Gy (50) }\end{array}$ & $\begin{array}{l}\text { Pre-treatment of ovarian cancer xenograft-bearing } \\
\text { mice with SLM or SS prevented an increase } \\
\text { in intracellular GSH in response } \\
\text { to cisplatin or melphalan (77) } \\
\text { MSA depletes intracellular GSH in THP-1 } \\
\text { leukaemia cells despite combination with } \\
\text { cisplatin, doxorubicin, Ara-C or radiation } 2 \mathrm{~Gy} \text { (50) }\end{array}$ & Favourable \\
\hline Cell death/cytotoxicity & $\begin{array}{l}\text { Protects against cisplatin-related } \\
\text { renal proximal tubule injury }(78) \\
\text { Clinical trial evidence of less } \\
\text { gastrointestinal, bone marrow, } \\
\text { renal and cardiac toxicity with } \\
\text { chemotherapy }(43-45,79) \text { and reduced } \\
\text { diarrhoea after radiation }(12,36,80)\end{array}$ & $\begin{array}{l}\text { Increased cytotoxicity in combination with } \\
\text { chemotherapy, tamoxifen or radiation in } \\
\text { several cell lines, including resistant } \\
\text { cells in vitro (13,81-85) } \\
\text { Therapeutic synergy between supra-nutritional } \\
\text { doses of Se (as SLM, SS, MSA and MSC) } \\
\text { and cisplatin, carboplatin, oxaliplatin, irinotecan, } \\
\text { docetaxel, fluorouracil and doxorubicin in human } \\
\text { tumour xenografts of small cell and non-small } \\
\text { cell lung carcinoma, colorectal carcinoma, } \\
\text { prostate carcinoma, head and neck squamous cell } \\
\text { carcinoma and leukaemia }(11,13,29-32) \\
\text { Clinical trials show either no compromised } \\
\text { outcome or improved outcome }(12,27,45,46)\end{array}$ & Favourable \\
\hline Angiogenesis & $\begin{array}{l}\text { MSC did not cause an increase in } \\
\text { chemotherapy drug delivery to } \\
\text { normal tissues (86) }\end{array}$ & $\begin{array}{l}\text { MSC resulted in improved tumor blood vessel } \\
\text { maturation and hypoxia with improved } \\
\text { chemotherapy drug delivery }(22,86)\end{array}$ & Favourable \\
\hline Radiosensitization & $\begin{array}{l}\text { No radiosensitization in normal } \\
\text { lung fibroblasts by SLM (87). } \\
\text { MSA did not increase PBMC } \\
\quad \text { death from RT (50). }\end{array}$ & $\begin{array}{l}\text { SLM caused radiosensitization in two human } \\
\text { lung cancer cell lines (87). }\end{array}$ & Favourable \\
\hline
\end{tabular}

Ara-C: cytosine arabinoside; Gy: gray; MSA: Methylseleninic acid; MSC: Se-methylselenocysteine; PBMCs: peripheral blood mononuclear cells; RT: radiotherapy Se: selenium; SLM: seleno-L-methionine; SS: sodium selenite.

treatment toxicity as the primary outcome $(24,47)$. In the head and neck trial 18 patients were randomised to pre-treatment with $3,600 \mu \mathrm{g} / \mathrm{m}^{2}$ SLM twice daily or placebo before radiotherapy and then daily thereafter. While no significant difference in grade 3 toxicities was observed, $50 \%$ of Setreated patients had grade $0-1$ mucositis compared to $25 \%$ in the placebo group (24). In addition, a trend for reduced highfrequency hearing loss in Se-treated patients was seen (Figure 3; unpublished data, M. Jameson). The single-arm NSCLC study in 16 patients, administering $4,800 \mu \mathrm{g} / \mathrm{m}^{2}$ SLM twice daily for 7 days pre-radiotherapy then daily during chemoradiation, reported no Se-related toxicity but a lower than expected rate of grade III or higher toxicities was observed, particularly for pneumonitis and anaemia (47).

\section{Conclusion}

While there have been major advances in cancer therapy in recent years, especially with the development of targetedtherapies, cytotoxic chemotherapy and radiation still remain a mainstay of treatment for many malignancies. The considerable toxicity of these treatments remains a major challenge in cancer management, one that has not been overcome despite extensive research into protective strategies (48).

In this context, Se appears to be unique in terms of its ability to protect against carcinogenesis as well as selectively target existing cancer cells and synergise with other cancer therapies, while protecting normal tissues from the cytotoxic effects of those treatments. These distinctive features enable, at least in preclinical models, administration of higher doses of cytotoxic agents than would be feasible otherwise, with improved cancer outcomes. If this widening of the notoriously narrow therapeutic index of cytotoxic treatments with $\mathrm{Se}$ is replicated in the clinical setting, this would represent a very significant advance in cancer management, and further clinical evaluation is clearly justified.

However, before large-scale clinical trials are undertaken to evaluate the ability of Se to modulate the efficacy and toxicity of anticancer therapies, more research is needed to determine which Se compound, and at what dose, can be 
Table III. Clinical trials evaluating outcomes when selenium compounds were given with chemotherapy and/or radiotherapy.

\begin{tabular}{|c|c|c|c|c|c|c|}
\hline $\begin{array}{l}\text { Author \& year } \\
\text { of publication }\end{array}$ & $\mathrm{N}$ & $\begin{array}{c}\text { Trial } \\
\text { design }\end{array}$ & $\begin{array}{l}\text { Cancer } \\
\text { treatment }\end{array}$ & $\begin{array}{l}\text { Cancer } \\
\text { type }\end{array}$ & $\begin{array}{l}\text { Selenium } \\
\text { form \& dose }\end{array}$ & $\begin{array}{l}\text { Outcomes - } \\
\text { toxicity/efficacy }\end{array}$ \\
\hline $\begin{array}{l}\text { Hu et al. } \\
1997 \text { (44) }\end{array}$ & 41 & $\begin{array}{l}\text { Randomised to Se } \\
\text { with cycle } 1 \text { or } \\
2 \text { (not both) }\end{array}$ & $\begin{array}{l}\text { Cisplatin-based } \\
\text { chemotherapy } \\
\left(60-80 \mathrm{mg} / \mathrm{m}^{2}\right)\end{array}$ & $\begin{array}{l}\text { Lung, breast, } \\
\text { gastric, colon, } \\
\text { oesophagus, } \\
\text { liver }\end{array}$ & $\begin{array}{l}\text { Oral kappa-seleno- } \\
\text { carrageenan ( } 4000 \mu \mathrm{g} \\
\text { Se/day for } 4 \text { days } \\
\text { before and after } \\
\text { chemotherapy) }\end{array}$ & $\begin{array}{c}\text { - Significantly higher day } 14 \mathrm{WBC} \\
3.35 \pm 2.01 \text { vs. } 2.31 \pm 1.38 \times 10^{9} / 1 \\
(p<0.05) \\
\text { - Less G-CSF and RBC transfusion } \\
\bullet \text { less nephrotoxicity }\end{array}$ \\
\hline $\begin{array}{l}\text { Sieja et al. } \\
2004 \text { (45) }\end{array}$ & 62 & $\begin{array}{l}\text { Randomised to } \\
\text { Se or not }\end{array}$ & $\begin{array}{l}\text { Cisplatin }\left(100 \mathrm{mg} / \mathrm{m}^{2}\right) \\
\text { and cyclophosphamide } \\
\quad\left(600 \mathrm{mg} / \mathrm{m}^{2}\right)\end{array}$ & Ovarian & $\begin{array}{l}\text { Oral selenized yeast } \\
200 \mu \mathrm{g} / \mathrm{day} \text { for } \\
3 \text { months }\end{array}$ & $\begin{array}{c}\text { - Significantly less nausea }(p<0.001), \\
\text { vomiting }(p<0.001), \text { stomatitis } \\
(p<0.0292), \text { abdominal pain } \\
(p<0.0006), \text { anorexia, weakness } \\
(p<0.001), \text { alopecia }(p<0.001) \\
\text { - Significantly higher neutrophils } \\
\text { - Trend to lower serum CA-125 } \\
(93.5 \pm 200 v s .228 \pm 713 \mathrm{U} / \mathrm{ml})\end{array}$ \\
\hline $\begin{array}{l}\text { Weijl et al. } \\
2004 \text { (88) }\end{array}$ & 48 & $\begin{array}{l}\text { Randomised to } \\
\text { vitamins C, E and } \\
\text { Se or placebo }\end{array}$ & $\begin{array}{l}\text { Cisplatin dose } \\
\text { intensity } \\
\left(60-100 \mathrm{mg} / \mathrm{m}^{2}\right)\end{array}$ & $\begin{array}{l}\text { Testicular, bone, } \\
\text { gastrointestinal, } \\
\text { urogenital, head } \\
\text { and neck, melanoma }\end{array}$ & $\begin{array}{l}\text { Oral sodium selenite } \\
100 \mu \mathrm{g} \text { daily } \\
\text { a }\end{array}$ & $\begin{array}{l}\text { - No improvement in toxicity } \\
\text { or response rate } \\
\text { - } 64 \% \text { Of supplement group } \\
\text { non-compliant due to GI effects } \\
\text { - Serum Se did not increase }\end{array}$ \\
\hline $\begin{array}{l}\text { Gounder et al. } \\
2005 \text { (89) }\end{array}$ & 11 & $\begin{array}{l}\text { Phase I dose } \\
\text { escalation }\end{array}$ & $\begin{array}{c}\text { Paclitaxel }\left(175 \mathrm{mg} / \mathrm{m}^{2}\right) \\
\text { and Carboplatin AUC } \\
5 \text { cycle } 1 \text { then AUC6 }\end{array}$ & $\begin{array}{c}\text { Gynaecologic } \\
\text { malignancies }\end{array}$ & $\begin{array}{l}\text { IV sodium selenite } \\
50 \mu \mathrm{g}, 100 \mu \mathrm{g} \text { or } \\
200 \mu \mathrm{g} \text { over } 5 \text { hours } \\
\text { two days prior to } \\
\text { chemotherapy }\end{array}$ & $\begin{array}{c}\text { - Selenite can be safely administered } \\
\text { with this chemotherapy } \\
\text { - No significant alteration of } \\
\text { predicted carboplatin AUC }\end{array}$ \\
\hline $\begin{array}{l}\text { Asfour et al. } \\
2006 \text { (79) }\end{array}$ & 30 & $\begin{array}{l}\text { Randomised to } \\
\text { Se or not }\end{array}$ & $\begin{array}{l}\text { Cyclophosphamide } \\
750 \mathrm{mg} / \mathrm{m}^{2}, \text { doxorubicin } \\
50 \mathrm{mg} / \mathrm{m}^{2} \text {, vincristine } \\
\left.1.4 \mathrm{mg} / \mathrm{m}^{2} \text { (all day } 1\right) \\
\text { and prednisone } 100 \mathrm{mg} \\
\text { daily x } 5,(\text { CHOP) } \\
\text { every } 4 \text { weeks }\end{array}$ & $\begin{array}{c}\text { Non-Hodgkin } \\
\text { lymphoma }\end{array}$ & $\begin{array}{l}\text { Oral sodium selenite } \\
200 \mu \mathrm{g} / \mathrm{kg} / \mathrm{day}\end{array}$ & $\begin{array}{l}- \text { Significantly less apoptosis of } \\
\text { neutrophils }(67 \% \text { vs. } 20 \%, \\
p<0.05) \text { and reduced infection rate } \\
\text { - Significantly better preservation } \\
\text { of cardiac ejection fraction } \\
(62+/-4 \% \text { vs. } 69 \pm 5 \% p<0.05) \text {. }\end{array}$ \\
\hline $\begin{array}{l}\text { Asfour et al. } \\
2007 \text { (27) }\end{array}$ & 50 & $\begin{array}{l}\text { Randomised to } \\
\text { Se or not }\end{array}$ & $\begin{array}{l}\text { CHOP (as for } \\
\text { Asfour 2006) }\end{array}$ & $\begin{array}{l}\text { Non-Hodgkin } \\
\text { lymphoma }\end{array}$ & $\begin{array}{l}\text { Oral sodium selenite } \\
200 \mu \mathrm{g} / \mathrm{kg} / \text { day } \\
\text { for first } 30 \text { days }\end{array}$ & $\begin{array}{l}- \text { Significant decline of } \mathrm{Bcl}-2 \text { level } \\
\text { in BM aspirate and increase in } \\
\text { CD4/CD8 ratio in peripheral blood } \\
\text { after } 3 \text { cycles }(8.6 \pm 6.9 \mathrm{ng} / \mathrm{ml} \mathrm{vs} \text {. } \\
36.9 \pm 7.9 \mathrm{ng} / \mathrm{ml}, p<0.05) \\
\text { - Increased complete response rate } \\
\text { in Se group }(60 \% \mathrm{vs} .40 \%)\end{array}$ \\
\hline $\begin{array}{l}\text { Fakih et al. } \\
2006(90)\end{array}$ & 13 & $\begin{array}{l}\text { Phase I dose } \\
\text { escalation study }\end{array}$ & $\begin{array}{l}\text { Irinotecan } 125- \\
160 \mathrm{mg} / \mathrm{m}^{2} \text { weekly }\end{array}$ & $\begin{array}{l}\text { Colorectal, lung, } \\
\text { pancreatic, gastric, } \\
\text { mesothelioma }\end{array}$ & $\begin{array}{c}\text { Oral seleno- } \\
\text { methionine } \\
2200 \mu \mathrm{g} \text { Se daily } \\
\text { starting 1 week } \\
\text { before chemotherapy }\end{array}$ & $\begin{array}{l}\text { - Irinotecan MTD } 125 \mathrm{mg} / \mathrm{m}^{2} \\
\text { - No diarrhoea > grade } 2 \text { at MTD } \\
\text { - Responses seen in irinotecan- } \\
\text { refractory population }\end{array}$ \\
\hline $\begin{array}{l}\text { Fakih et al. } \\
2008(25)\end{array}$ & 31 & $\begin{array}{l}\text { Phase I and } \\
\text { PK study }\end{array}$ & $\begin{array}{l}\text { Irinotecan } 125 \mathrm{mg} / \mathrm{m}^{2} \\
\text { weekly x } 4 \text { every } \\
6 \text { weeks }\end{array}$ & $\begin{array}{l}\text { Metastatic or } \\
\text { unresectable } \\
\text { solid tumour }\end{array}$ & $\begin{array}{l}\text { Oral seleno- } \\
\text { methionine; dose } \\
\text { escalation from } \\
2800-7200 \mu \mathrm{g} / \text { day } \\
\text { maintenance (twice } \\
\text { daily loading for } 1 \\
\text { week prior to starting } \\
\text { irinotecan) }\end{array}$ & $\begin{array}{c}\text { - Prolonged stable disease } \\
>6 \text { months in irinotecan- } \\
\text { pre-treated patients } \\
\text { - SLM well-tolerated at } 7200 \mu \mathrm{g} \\
\text { twice daily for } 1 \text { week } \\
\text { followed by } 7,200 \mu \mathrm{g} \\
\text { daily with irinotecan } \\
\text { - No reduction in irinotecan toxicity }\end{array}$ \\
\hline $\begin{array}{l}\text { Asfour et al. } \\
2009 \text { (46) }\end{array}$ & 40 & $\begin{array}{l}\text { Randomised to } \\
\text { Se or not }\end{array}$ & $\begin{array}{l}\text { CHOP (as for } \\
\text { Asfour 2006) }\end{array}$ & $\begin{array}{l}\text { Non-Hodgkin's } \\
\text { lymphoma }\end{array}$ & $\begin{array}{l}\text { Oral sodium selenite } \\
200 \mu \mathrm{g} / \mathrm{kg} / \mathrm{day} \\
\text { for } 5 \text { days }\end{array}$ & $\begin{array}{l}\text { - Significantly greater increase in } \\
\text { apoptotic marrow cells on day } 8 \text { of } \\
\text { cycle } 1 \text { in Se group ( } 49.2 \% \text { vs. } 29.7 \%) \\
\text { - Significant increase in tumour reduction } \\
\text { - Preservation of cardiac ejection } \\
\text { fraction in Se group but } \\
\text { not controls }(p=0.04)\end{array}$ \\
\hline
\end{tabular}


Table III. Continued

\begin{tabular}{lccccc}
\hline $\begin{array}{l}\text { Author \& year } \\
\text { of publication }\end{array}$ & $\mathrm{N}$ & $\begin{array}{c}\text { Trial } \\
\text { design }\end{array}$ & $\begin{array}{c}\text { Cancer } \\
\text { treatment }\end{array}$ & $\begin{array}{c}\text { Cancer } \\
\text { type }\end{array}$ & $\begin{array}{c}\text { Selenium } \\
\text { form \& dose }\end{array}$ \\
\hline $\begin{array}{l}\text { Muecke } \text { et al. } \\
2010.2014\end{array}$ & 81 & $\begin{array}{c}\text { Randomized to Se } \\
\text { or not in patients } \\
(12,35)\end{array}$ & $\begin{array}{c}\text { Radiotherapy }(\mathrm{RT}) \\
\text { (external beam } \\
\text { Se }(<84 \mathrm{ng} / \mathrm{ml})\end{array}$ & $\begin{array}{c}\text { Endometrium } \\
\text { or cervix } \\
\text { therapy) }\end{array}$ & $\begin{array}{c}\text { Oral sodium selenite } \\
500 \mu \mathrm{g} \text { on days of }\end{array}$ \\
& & RT and $300 \mu \mathrm{g}$ on days \\
without treatment
\end{tabular}

Buntzel et al. 47 or Randomised to Se 2010 (2 papers with overlapping 39 or not in patients cohorts)

$(36,80)$

Corcoran et al. $19 \quad$ Phase I dose 2010 (26)

\section{RT (37/39 adjuvant)} (not defined) escalation discontinued

\section{Antiandrogens} $>4$ weeks before trial; LHRH agonists were continued

High-dose busulfan

+ cyclophosphamide then allogeneic haematopoietic stem cell transplantation

Vieira et al. 39 2015 (91)

Mix et al. 2015 (24)

$\begin{array}{ccc}\text { Mix et al. } & 16 & \begin{array}{c}\text { Single arm } \\ \text { phase II study } \\ \text { of SLM }\end{array}\end{array}$

Randomised,
placebo-
controlled
crossover;
both placebo
periods were
grouped for
analysis (half
had Se first)

Various chemotherapy regimens (timing of Se supplementation not specified)

Concurrent chemoradiation (CCRT). RT 70 Gy over 7 weeks; cisplatin $100 \mathrm{mg} / \mathrm{m}^{2}$ on days 1,22 and 43 of RT

CCRT with RT 60-66 Gy and weekly paclitaxel $50 \mathrm{mg} / \mathrm{m}^{2}$

\section{Head and neck squamous carcinoma}
Chemotherapy- naïve, castration- resistant prostate cancer

Acute leukaemia

Oral selenized yeast $(200 \mu \mathrm{g})$ $v s$. placebo twice daily from day 0 to 14 days after transplant

Paediatric
leukaemia
or lymphoma
(LL) or various
solid tumours
(ST)

Selenium-glycine age-dependent dosing (27-

$100 \mu \mathrm{g} /$ day) for

30 days, 7 days washout then alternate medication for 30 days. Sustained dosing for 12 months in 16 patients. and carboplatin

AUC 2 over 6 weeks
Stage III-IV head SLM at $3600 \mu \mathrm{g} / \mathrm{m}^{2}$ and neck twice daily presquamous treatment for 7 days cell cancer and daily until 3 weeks after chemoradiation completion or placebo.

Stage III SLM at $4800 \mu \mathrm{g} / \mathrm{m}^{2}$

NSCLC twice daily pretreatment for 7 days and daily for 6 weeks or completion of chemoradiation.

\author{
Outcomes -
}

toxicity/efficacy
- Significant increase in blood Se

- Less $\geq$ grade 2 diarrhoea $(20.5 \%$ vs. $44.5 \%, p=0.04)$

- 5-Year survival $91.9 \%$ vs. $83.1 \%$ ( $p=\mathrm{NS}$ )

- 10 -Year survival 55.3\% vs. $42.1 \%$ ( $p=\mathrm{NS})$

- No Se side-effects observed

- Significantly less dysphagia in the last week of RT

- Trend to less acute taste loss

- No difference in xerostomia or mucositis

- Significant transient increase in serum and whole blood Se

- MTD was 60,000 $\mu \mathrm{g} / \mathrm{day}$ with linear PK

- fatigue, diarrhoea and muscle spasms dose-limiting at $90.000 \mu \mathrm{g} / \mathrm{day}$

- One PSA response $>50 \%$ and mean PSA doubling time increased (2.18 months before trial to 3.85 months)

- Significant reduction in incidence of grades 3-4 oral mucositis (OM) $(10.8 \%$ vs. $35.1 \%)$

- Significantly shorter

- Significantly shorter duration of grades 2-4 OM

(3.6 \pm 1.8 days $v s .5 .2 \pm 2.2$ days)

- No significant change in EORTC QLQ-C30 scores for fatigue, nausea, appetite loss, physical function in LL group

- Significant improvement in scores for nausea and appetite loss in ST group with both Se and placebo, for fatigue with placebo and for fatigue at 1 year with Se

- Significant decrease in serum AST levels with Se $(p=0.045)$

- General trend to improvement in scores

- No significant change in mucositis or patient reported side effects

- No difference in OS or RFS at 12 months

- No Se-related toxicity observed - Lower than expected rates of grade III or higher toxicities observed particularly for pneumonitis and anaemia 
Table III. Continued

\begin{tabular}{|c|c|c|c|c|c|c|}
\hline $\begin{array}{l}\text { Author \& year } \\
\text { of publication }\end{array}$ & $\mathrm{N}$ & $\begin{array}{l}\text { Trial } \\
\text { design }\end{array}$ & $\begin{array}{c}\text { Cancer } \\
\text { treatment }\end{array}$ & $\begin{array}{c}\text { Cancer } \\
\text { type }\end{array}$ & $\begin{array}{l}\text { Selenium } \\
\text { form \& dose }\end{array}$ & $\begin{array}{c}\text { Outcomes - } \\
\text { toxicity/efficacy }\end{array}$ \\
\hline $\begin{array}{l}\text { Brodin } \\
\text { et al. } \\
2015(92)\end{array}$ & 34 & $\begin{array}{l}\text { Phase I dose } \\
\text { escalation study }\end{array}$ & $\begin{array}{l}\text { Chemotherapy given } \\
\text { after intravenous } \\
\text { SS (retreated with } \\
\text { first-line } \\
\text { chemotherapy) }\end{array}$ & $\begin{array}{l}\text { Cancer patients } \\
\text { refractory to } \\
\text { cytostatic } \\
\text { drugs }\end{array}$ & $\begin{array}{c}\text { Intravenous SS } \\
\text { given on } 5 \text { of } \\
7 \text { days for either } \\
2 \text { or } 4 \text { weeks; } \\
\text { dose escalation } \\
\text { to MTD }\end{array}$ & $\begin{array}{c}\text { - Protocol defined MTD of } \\
10.2 \mathrm{mg} / \mathrm{m}^{2} \\
\text { - DLTs reported to be acute, of } \\
\text { short duration and reversible, } \\
\text { namely fatigue, nausea, } \\
\text { finger and leg cramps }\end{array}$ \\
\hline
\end{tabular}

AUC: Area under the curve; BM: bone marrow; DLT: dose-limiting toxicity; AST: aspartate aminotransferase; EORTC-QLQ-C30 The European Organisation for Research and Treatment of Cancer quality of life questionnaire C30; CCRT: Concurrent chemoradiation G-CSF: granulocyte colonystimulating factor; GI: gastrointestinal; Gy: gray; LHRH: luteinizing hormone-releasing hormone; LL: leukaemia or lymphoma; MTD: maxium tolerated dose; OM: oral mucositis OS: overall survival; PK: pharmacokinetic: PSA: prostate-specific antigen; RBC: red blood cell; RFS: relapsefree survival; RT: radiotherapy; Se: selenium; SLM: seleno-L-methionine; SS: sodium selenite; ST: solid tumours; WBC: white blood cell count.

most safely and effectively used in such trials in patients with cancer. The preclinical data suggest that organic Se compounds (such as MSC and SLM) are safer and likely more effective than inorganic compounds such as SS, particularly at the higher doses that appear to be optimal for anticancer efficacy and beneficial interactions with chemotherapy and radiation.

More rigorous evaluation in clinical trials is needed to characterise the relationship between PK and PD endpoints and comparative safety (including genotoxicity) for the $\mathrm{Se}$ compounds in clinical use. Innovative trial designs could include patients selected with malignancies that enable the evaluation of differential effects of Se compounds in normal cells and malignant cells. These trials are critical to inform the selection of the optimal Se compound and dose for future clinical trials and equally to avoid less effective or more toxic forms and doses of Se.

\section{References}

1 Shamberger RJ and Frost DV: Possible protective effect of selenium against human cancer. Can Med Assoc J 100: 682, 1969.

2 Combs GFJ: Selenium in global food systems. Br J Nutr 85: 517-547, 2001.

3 Rayman MP: Selenium in cancer prevention: a review of the evidence and mechanism of action. Proc Nutr Soc 64: 527-542, 2005.

4 Clark LC, Combs GFJ, Turnbull BW, Slate EH, Chalker DK, Chow J, Davis LS, Glover RA, Graham GF, Gross EG, Krongrad A, Lesher JLJ, Park HK, Sanders BBJ, Smith CL and Taylor JR: Effects of selenium supplementation for cancer prevention in patients with carcinoma of the skin. A randomized controlled trial. Nutritional Prevention of Cancer Study Group. JAMA 276: 1957-1963, 1996.

5 Lippman SM, Klein EA, Goodman PJ, Lucia MS, Thompson IM, Ford LG, Parnes HL, Minasian LM, Gaziano JM, Hartline
JA, Parsons JK, Bearden JD, III, Crawford ED, Goodman GE, Claudio J, Winquist E, Cook ED, Karp DD, Walther P, Lieber MM, Kristal AR, Darke AK, Arnold KB, Ganz PA, Santella RM, Albanes D, Taylor PR, Probstfield JL, Jagpal TJ, Crowley JJ, Meyskens FL Jr., Baker LH and Coltman CA Jr.: Effect of selenium and vitamin $\mathrm{E}$ on risk of prostate cancer and other cancers: the Selenium and Vitamin E Cancer Prevention Trial (SELECT). JAMA 301: 39-51, 2009.

6 Rayman MP: Selenium and human health. Lancet 379: 12561268, 2012.

7 Duffield-Lillico AJ, Reid ME, Turnbull BW, Combs GF Jr., Slate EH, Fischbach LA, Marshall JR and Clark LC: Baseline characteristics and the effect of selenium supplementation on cancer incidence in a randomized clinical trial: a summary report of the Nutritional Prevention of Cancer Trial. Cancer Epidemiology Biomarkers Prevention 11: 630-639, 2002.

8 Zermann DH: Demand for and clinical practice of complementary selenium therapy in prostate cancer patients. Forsch Komplementmed 19: 38-42, 2012 (in German).

9 Wagholikar A, Fung $M$ and Nelson C: A pilot study on understanding the journey of advanced prostate cancer patients. Stud Health Technol Inform 168: 165-171, 2011.

10 Stratton MS, Algotar AM, Ranger-Moore J, Stratton SP, Slate EH, Hsu CH, Thompson PA, Clark LC and Ahmann FR: Oral selenium supplementation has no effect on prostate-specific antigen velocity in men undergoing active surveillance for localized prostate cancer. Cancer Prev Res 3: 1035-1043, 2010.

11 Fakih M, Cao S, Durrani FA and Rustum YM: Selenium protects against toxicity induced by anticancer drugs and augments antitumor activity: a highly selective, new, and novel approach for the treatment of solid tumors. Clin Colorectal Cancer 5: 132135, 2005.

12 Muecke R, Schomburg L, Glatzel M, Berndt-Skorka R, Baaske D, Reichl B, Buentzel J, Kundt G, Prott FJ, Devries A, Stoll G, Kisters K, Bruns F, Schaefer U, Willich N and Micke O: Multicenter, phase 3 trial comparing selenium supplementation with observation in gynecologic radiation oncology. Int J Radiat Oncol Biol Phys 78: 828-835, 2010.

13 Cao S, Durrani FA and Rustum YM: Selective modulation of the therapeutic efficacy of anticancer drugs by selenium containing 
compounds against human tumor xenografts. Clin Cancer Res 10: 2561-2569, 2004.

14 Valdiglesias V, Pasaro E, Mendez J and Laffon B: In vitro evaluation of selenium genotoxic, cytotoxic, and protective effects: a review. Arch Toxicol 84: 337-351, 2010.

15 Combs GFJ, Clark LC and Turnbull BW: An analysis of cancer prevention by selenium. Biofactors 14: 153-159, 2001.

16 Thomson CD, Robinson MF, Butler JA and Whanger PD: Longterm supplementation with selenate and selenomethionine: selenium and glutathione peroxidase (EC 1.11.1.9) in blood components of New Zealand women. Br J Nutr 69: 577-588, 1993.

17 Rayman MP: Food-chain selenium and human health: emphasis on intake. Br J Nutr 100: 254-268, 2008.

18 Reid ME, Stratton MS, Lillico AJ, Fakih M, Natarajan R, Clark LC and Marshall JR: A report of high-dose selenium supplementation: response and toxicities. J Trace Elem Med Biol 18: 69-74, 2004.

19 Aguilar F, Charrondiere UR, Dusemund B, Galtier P, Gilbert J, Gott DM, Grilli S, Guertler R, Cass GEN, Koenig J, Lambre C, Larsen J-C, Leblanc J-C, Mortensen a, Parent-Massin D, Pratt I, Rietjens IMCM, Stankovic I, Tobback P, Verguieva $T$ and Woutersen R: Scientific Opinion of the Panel on Food Additives and Nutrient Sources added to Food on Se-Methyl-LSelenocysteine as a source of selenium added for nutritional purposes to food supplements following a request from the European Commission. EFSA J 1067: 1-23, 2009.

20 Vinceti M, Wei ET, Malagoli C, Bergomi M and Vivoli G: Adverse health effects of selenium in humans. Rev Environ Health 16: 233-251, 2001.

21 Ip C: Lessons from basic research in selenium and cancer prevention. J Nutr 128: 1845-1854, 1998.

22 Bhattacharya A: Methylselenocysteine: a promising antiangiogenic agent for overcoming drug delivery barriers in solid malignancies for therapeutic synergy with anticancer drugs. Expert Opin Drug Deliv 8: 749-763, 2011.

23 Marshall JR, Ip C, Romano K, Fetterly G, Fakih MG, Jovanovic BD, Perloff M, Crowell J, Davis W Jr., Christy R, Dew A, Coomes M and Bergan RC: Methyl Selenocysteine: single-dose pharmacokinetics in men. Cancer Prev Res 4: 1938-1944, 2011.

24 Mix M, Singh AK, Tills M, Dibaj S, Groman A, Jaggernauth W, Rustum Y and Jameson MB: Randomized phase II trial of selenomethionine as a modulator of efficacy and toxicity of chemoradiation in squamous cell carcinoma of the head and neck. World J Clin Oncol 6: 166-173, 2015.

25 Fakih MG, Pendyala L, Brady W, Smith PF, Ross ME, Creaven PJ, Badmaev V, Prey JD and Rustum YM: A Phase I and pharmacokinetic study of selenomethionine in combination with a fixed dose of irinotecan in solid tumors. Cancer Chemother Pharmacol 62: 499-508, 2008

26 Corcoran NM, Hovens CM, Michael M, Rosenthal MA and Costello AJ: Open-label, phase I dose-escalation study of sodium selenate, a novel activator of PP2A, in patients with castrationresistant prostate cancer. Br J Cancer 103: 462-468, 2010.

27 Asfour IA, Fayek M, Raouf S, Soliman M, Hegab HM, El Desoky H, Saleh R and Moussa MA: The impact of high-dose sodium selenite therapy on BCL2 expression in adult nonHodgkin's lymphoma patients: correlation with response and survival. Biol Trace Elem Res 120: 1-10, 2007.

28 Stevens J, Juliger S, Summer K, Fitzgibbon J, Lister A and Joel $\mathrm{S}$ : Methylseleninic acid demonstrates anti-leukaemic activity and sensitises AML cells to the effects of cytotoxic agents by initiating the unfolded protein response. Congress of the European Hematology Association Copenhagen, Denmark, June 12-15, 2008. Haematologica 93(s1): 115-116, 2008.

$29 \mathrm{Hu} \mathrm{H}$, Jiang C, Ip C, Rustum YM and Lu J: Methylseleninic acid potentiates apoptosis induced by chemotherapeutic drugs in androgen-independent prostate cancer cells. Clin Cancer Res 11: 2379-2388, 2005.

30 Cao S, Durrani FA and Rustum YM: Se-(Methyl)selenocysteine (MSC) potentiates the antitumor activity of platinum compounds and protects against drug induced toxicity in rats bearing advanced colorectal carcinoma. Cancer Res 65: 1209-1209,2005.

31 Frenkel, GD and Caffrey PB:Prevention of carboplatin-induced resistance in human ovarian tumor xenografts. Cancer Res 65 : 351-351,2005.

32 Frenkel GD and Caffrey PB: A prevention strategy for circumventing drug resistance in cancer chemotherapy. Curr Pharm Des 7: 1595-1614, 2001.

33 Bhattacharya A, Mazurchuk R, Spernyak JA, Tóth K, Magnano CR, Cao S, Azrak RG, Durrani FA and Rustum YM: Tumor vessel maturation by 5-Methylselenocysteine (MSC) results in synergistic antitumor effect in human head and neck squamous cell carcinoma (HNSCC) xenografts. Cancer Res 66: 413-414, 2006.

34 Muecke R, Reichl B, Glatzel M, Baaske D, Berndt-Skorka R, Buentzel J, Prott F and Micke O: Sodium selenite in gynecologic radiation oncology-final results of a prospective randomized observation study. Int J Radiat Oncol Biol Phys 69: S393, 2007.

35 Muecke R, Micke O, Schomburg L, Glatzel M, Reichl B, Kisters K, Schaefer U, Huebner J, Eich HT, Fakhrian K, Adamietz IA and Buentzel J: Multicenter, phase III trial comparing selenium supplementation with observation in gynecologic radiation oncology: follow-up analysis of the survival data 6 years after cessation of randomization. Integr Cancer Ther 13: 463-467, 2014.

36 Buntzel J, Riesenbeck D, Glatzel M, Berndt-Skorka R, Riedel T, Mucke R, Kisters K, Schonekaes KG, Schafer U, Bruns F and Micke O: Limited effects of selenium substitution in the prevention of radiation-associated toxicities. results of a randomized study in head and neck cancer patients. Anticancer Res 30: 1829-1832, 2010.

37 Francescato HD, Costa RS, Rodrigues Camargo SM, Zanetti MA, Lavrador MA and Bianchi MD: Effect of oral selenium administration on cisplatin-induced nephrotoxicity in rats. Pharmacol Res 43: 77-82, 2001.

38 Rao M and Rao MN: Protective effects of selenomethionine against cisplatin-induced renal toxicity in mice and rats. J Pharm Pharmacol 50: 687-691, 1998.

39 Ohkawa K, Tsukada Y, Dohzono H, Koike K and Terashima Y: The effects of co-administration of selenium and cis-platin (CDDP) on CDDP-induced toxicity and antitumour activity. $\mathrm{Br}$ J Cancer 58: 38-41, 1988.

40 Satoh M, Naganuma A and Imura N: Optimum schedule of selenium administration to reduce lethal and renal toxicities of cis-diamminedichloroplatinum in mice. J Pharmacobiodyn 12: 246-253, 1989.

41 Yoshida M, Iizuka K, Terada A, Hara M, Nishijima H, Akinori, Shimada, Nakada K, Satoh Y and Akama Y: Prevention of nephrotoxicity of cisplatin by repeated oral administration of ebselen in rats. Tohoku J Exp Med 191: 209-220, 2000. 
42 Araya Y: Studies on protective effect of selenium on the nephrotoxicity of cis-diamminedichloroplatinum (CDDP) in mice. Hokkaido Igaku Zasshi 65: 245-253, 1990 (in Japanese).

43 Jahangard-Rafsanjani Z, Gholami K, Hadjibabaie M, Shamshiri AR, Alimoghadam K, Sarayani A, Mojtahedzadeh M, OstadaliDehaghi $M$ and Ghavamzadeh A: The efficacy of selenium in prevention of oral mucositis in patients undergoing hematopoietic SCT: a randomized clinical trial. Bone Marrow Transplant 48: 832-836, 2013.

$44 \mathrm{Hu}$ YJ, Chen Y, Zhang YQ, Zhou MZ, Song XM, Zhang BZ, Luo L, Xu PM, Zhao YN, Zhao YB and Cheng G: The protective role of selenium on the toxicity of cisplatin-contained chemotherapy regimen in cancer patients. Biol Trace Elem Res 56: 331-341, 1997.

45 Sieja K and Talerczyk M: Selenium as an element in the treatment of ovarian cancer in women receiving chemotherapy. Gynecol Oncol 93: 320-327, 2004.

46 Asfour IA, El Tehewi MM, Ahmed MH, Abdel-Sattar MA, Moustafa NN, Hegab HM and Fathey OM: High-dose sodium selenite can induce apoptosis of lymphoma cells in adult patients with non-Hodgkin's lymphoma. Biol Trace Elem Res 127: 200210, 2009

47 Mix M, Ramnath N, Gomez J, de GC, Rajan S, Dibaj S, Tan W, Rustum Y, Jameson $\mathrm{MB}$ and Singh AK: Effects of selenomethionine on acute toxicities from concurrent chemoradiation for inoperable stage III non-small cell lung cancer. World J Clin Oncol 6: 156-165, 2015.

48 Hensley ML, Hagerty KL, Kewalramani T, Green DM, Meropol NJ, Wasserman TH, Cohen GI, Emami B, Gradishar WJ, Mitchell RB, Thigpen JT, Trotti A, 3rd, von Hoff D and Schuchter LM: American Society of Clinical Oncology 2008 clinical practice guideline update: use of chemotherapy and radiation therapy protectants. J Clin Oncol 27: 127-145, 2009.

49 de R, V, Erkekoglu P, Forestier A, Favier A, Hincal F, Diamond $\mathrm{AM}$, Douki $\mathrm{T}$ and Rachidi W: Low doses of selenium specifically stimulate the repair of oxidative DNA damage in LNCaP prostate cancer cells. Free Radic Res 46: 105-116, 2012.

50 Jameson MB, Lobb RJ, Jacobson GM and Cursons RT: Differential effects of selenium (Se) on normal and malignant cells treated with chemotherapy (CT) and radiation (RT). J Clin Oncol 31: e13583-e13583, 2013.

51 Selenius M, Rundlof AK, Olm E, Fernandes AP and Bjornstedt $\mathrm{M}$ : Selenium and the selenoprotein thioredoxin reductase in the prevention, treatment and diagnostics of cancer. Antioxid Redox Signal 12: 867-880, 2010

52 Karunasinghe N, Han DY, Zhu S, Duan H, Ko YJ, Yu JF, Triggs $\mathrm{CM}$ and Ferguson LR: Effects of supplementation with selenium, as selenized yeast, in a healthy male population from New Zealand. Nutr Cancer 65: 355-366, 2013.

53 Selenius M, Fernandes AP, Brodin O, Bjornstedt M and Rundlof AK: Treatment of lung cancer cells with cytotoxic levels of sodium selenite: effects on the thioredoxin system. Biochem Pharmacol 75: 2092-2099, 2008.

54 Jonsson-Videsater K, Bjorkhem-Bergman L, Hossain A, Soderberg A, Eriksson LC, Paul C, Rosen A and Bjornstedt M: Selenite-induced apoptosis in doxorubicin-resistant cells and effects on the thioredoxin system. Biochem Pharmacol 67: 513522,2004

55 Nilsonne G, Sun X, Nystrom C, Rundlof AK, Potamitou FA, Bjornstedt $\mathrm{M}$ and Dobra K: Selenite induces apoptosis in sarcomatoid malignant mesothelioma cells through oxidative stress. Free Radic Biol Med 41: 874-885, 2006.

56 Erzinger MM, Bovet C, Uzozie A and Sturla SJ: Induction of complementary function reductase enzymes in colon cancer cells by dithiole-3-thione versus sodium selenite. J Biochem Mol Toxicol 29: 10-20, 2015.

57 Wallenberg M, Misra S, Wasik AM, Marzano C, Bjornstedt M, Gandin V and Fernandes AP: Selenium induces a multi-targeted cell death process in addition to ROS formation. J Cell Mol Med 18: 671-684, 2014.

58 Suzuki M, Endo M, Shinohara F, Echigo S and Rikiishi H: Differential apoptotic response of human cancer cells to organoselenium compounds. Cancer Chemother Pharmacol 66: 475-484, 2010

$59 \mathrm{Wu}$ Y, Zhang H, Dong Y, Park YM and Ip C: Endoplasmic reticulum stress signal mediators are targets of selenium action. Cancer Res 65: 9073-9079, 2005.

60 Fischer JL, Lancia JK, Mathur A and Smith ML: Selenium protection from DNA damage involves a REF1/P53/BRCA1 protein complex. Anticancer Res 26: 899-904, 2006.

61 Seo YR, Sweeney C and Smith ML: Selenomethionine induction of DNA repair response in human fibroblasts. Oncogene 21: 3663-3669, 2002.

62 Jung HJ, Kim HL, Kim YJ, Weon JI and Seo YR: A novel chemopreventive mechanism of selenomethionine: enhancement of APE1 enzyme activity via a Gadd45a, PCNA and APE1 protein complex that regulates p53-mediated base excision repair. Oncol Rep 30: 1581-1586, 2013.

63 Fischer JL, Cao S, Durrani FA, Fakih M, Rustum YM and Smith ML: Chemotherapeutic selectivity conferred by selenium: A role for p53-dependent DNA repair. Cancer Res 66: 127-128, 2006.

64 Jiang C, Kim KH, Wang Z and Lu J: Methyl selenium-induced vascular endothelial apoptosis is executed by caspases and principally mediated by p38 MAPK pathway. Nutr Cancer 49 : 174-183, 2004

$65 \mathrm{Lu} \mathrm{J}$ and Jiang C: Antiangiogenic activity of selenium in cancer chemoprevention: metabolite-specific effects. Nutr Cancer 40: 64-73, 2001.

66 Chintala S, Toth K, Cao S, Durrani FA, Vaughan MM, Jensen RL and Rustum YM: Se-methylselenocysteine sensitizes hypoxic tumor cells to irinotecan by targeting hypoxia-inducible factor 1alpha. Cancer Chemother Pharmacol 66: 899-911, 2010.

67 Chintala S, Najrana T, Toth K, Cao S, Durrani FA, Pili R and Rustum YM: Prolyl hydroxylase 2 dependent and Von-HippelLindau independent degradation of Hypoxia-inducible factor 1 and 2 alpha by selenium in clear cell renal cell carcinoma leads to tumor growth inhibition. BMC Cancer 12: 293, 2012.

68 Jiang C, Ganther $\mathrm{H}$ and Lu J: Monomethyl selenium--specific inhibition of MMP-2 and VEGF expression: implications for angiogenic switch regulation. Mol Carcinog 29: 236-250, 2000.

69 Yin MB, Li ZR, Toth K, Cao S, Durrani FA, Hapke G, Bhattacharya A, Azrak RG, Frank $\mathrm{C}$ and Rustum YM: Potentiation of irinotecan sensitivity by Se-methylselenocysteine in an in vivo tumor model is associated with downregulation of cyclooxygenase-2, inducible nitric oxide synthase, and hypoxiainducible factor 1alpha expression, resulting in reduced angiogenesis. Oncogene 25: 2509-2519, 2006.

70 Bhattacharya A, Toth K, Sen A, Seshadri M, Cao S, Durrani FA, Faber E, Repasky EA and Rustum YM: Inhibition of colon cancer growth by methylselenocysteine-induced angiogenic 
chemomodulation is influenced by histologic characteristics of the tumor. Clin Colorectal Cancer 8: 155-162, 2009.

71 Park JM, Kim A, Oh JH and Chung AS: Methylseleninic acid inhibits PMA-stimulated pro-MMP-2 activation mediated by MT1-MMP expression and further tumor invasion through suppression of NF-kappaB activation. Carcinogenesis 28: 837847, 2007.

72 Yoon S-O, Kim M-M and Chung A-S: Inhibitory Effect of Selenite on Invasion of HT1080 Tumor Cells. J Biol Chem 276: 20085-20092, 2001.

73 Xiang N, Zhao R, Song G and Zhong W: Selenite reactivates silenced genes by modifying DNA methylation and histones in prostate cancer cells. Carcinogenesis 29: 2175-2181, 2008.

$74 \mathrm{Hu}$ C, Liu M, Zhang W, Xu Q, Ma K, Chen L, Wang Z, He S, Zhu $\mathrm{H}$ and $\mathrm{Xu} \mathrm{N}$ : Upregulation of KLF4 by methylseleninic acid in human esophageal squamous cell carcinoma cells: Modification of histone $\mathrm{H} 3$ acetylation through HAT/HDAC interplay. Mol Carcinog 54: 1051-1059, 2015.

75 Hoffmann FW, Hashimoto AC, Shafer LA, Dow S, Berry MJ and Hoffmann PR: Dietary selenium modulates activation and differentiation of $\mathrm{CD}^{+}{ }^{+} \mathrm{T}$-cells in mice through a mechanism involving cellular free thiols. J Nutr 140: 1155-1161, 2010.

76 Azrak RG, Yu J, Pendyala L, Smith PF, Cao S, Li X, Shannon WD, Durrani FA, McLeod HL and Rustum YM: Irinotecan pharmacokinetic and pharmacogenomic alterations induced by methylselenocysteine in human head and neck xenograft tumors. Mol Cancer Ther 4: 843-854, 2005.

77 Caffrey PB and Frenkel GD: Selenium compounds prevent the induction of drug resistance by cisplatin in human ovarian tumor xenografts in vivo. Cancer Chemother Pharmacol 46: 74-78, 2000 .

78 Camargo SM, Francescato HD, Lavrador MA and Bianchi ML: Oral administration of sodium selenite minimizes cisplatin toxicity on proximal tubules of rats. Biol Trace Elem Res 83: 251-262, 2001.

79 Asfour IA, El Shazly S, Fayek MH, Hegab HM, Raouf S and Moussa MA: Effect of high-dose sodium selenite therapy on polymorphonuclear leukocyte apoptosis in non-Hodgkin's lymphoma patients. Biol Trace Elem Res 110: 19-32, 2006.

80 Buntzel J, Micke O, Kisters K, Bruns F, Glatzel M, Schonekaes K, Kundt G, Schafer U and Mucke R: Selenium substitution during radiotherapy of solid tumours - laboratory data from two observation studies in gynaecological and head and neck cancer patients. Anticancer Res 30: 1783-1786, 2010.

81 Zhang Y, Zheng S, Zheng JS, Wong KH, Huang Z, Ngai SM, Zheng W, Wong YS and Chen T: Synergistic induction of apoptosis by methylseleninic acid and cisplatin, the role of ROSERK/AKT-p53 pathway. Mol Pharm 11: 1282-1293, 2014.

82 Li S, Zhou Y, Wang R, Zhang H, Dong Y and Ip C: Selenium sensitizes MCF-7 breast cancer cells to doxorubicin-induced apoptosis through modulation of phospho-Akt and its downstream substrates. Mol Cancer Ther 6: 1031-1038, 2007.

83 Qi Y, Fu X, Xiong Z, Zhang H, Hill SM, Rowan BG and Dong Y: Methylseleninic acid enhances paclitaxel efficacy for the treatment of triple-negative breast cancer. PLoS One 7: e31539, 2012.
84 Tzeng TJ, Cao L, Fu Y, Zeng H and Cheng WH: Methylseleninic acid sensitizes Notch3-activated OVCA429 ovarian cancer cells to carboplatin. PLoS One 9: e101664, 2014.

$85 \mathrm{Li}$ Z, Carrier L and Rowan BG: Methylseleninic acid synergizes with tamoxifen to induce caspase-mediated apoptosis in breast cancer cells. Mol Cancer Ther 7: 3056-3063, 2008.

86 Azrak RG, Cao S, Durrani FA, Toth K, Bhattacharya A and Rustum YM: Augmented therapeutic efficacy of irinotecan is associated with enhanced drug accumulation. Cancer Lett 311 : 219-229, 2011.

87 Shin SH, Yoon MJ, Kim M, Kim JI, Lee SJ, Lee YS and Bae S: Enhanced lung cancer cell killing by the combination of selenium and ionizing radiation. Oncol Rep 17: 209-216, 2007.

88 Weijl NI, Elsendoorn TJ, Lentjes EG, Hopman GD, WipkinkBakker A, Zwinderman AH, Cleton FJ and Osanto S: Supplementation with antioxidant micronutrients and chemotherapy-induced toxicity in cancer patients treated with cisplatin-based chemotherapy: a randomised, double-blind, placebo-controlled study. Eur J Cancer 40: 1713-1723, 2004.

89 Gounder MK, Gibbon D, Kumar CA, Simmons N, Buckley B, Xie R, Lin Y, Shih W, Frenkel GD, Caffrey P, Rubin EH and Rodrigeuz-Rodriguez L: A phase I and pharmacokinetic study of paclitaxel and carboplatin combined with sodium selenite in patients with gynecologic malignacies. Cancer Res 65: 938-938, 2005.

90 Fakih MG, Pendyala L, Smith PF, Creaven PJ, Reid ME, Badmaev V, Azrak RG, Prey JD, Lawrence D and Rustum YM: A phase I and pharmacokinetic study of fixed-dose selenomethionine and irinotecan in solid tumors. Clin Cancer Res 12: 1237-1244, 2006.

91 Vieira ML, Fonseca FL, Costa LG, Beltrame RL, Chaves CM, Cartum J, Alves SI, Azzalis LA, Junqueira VB, Pereria EC and Rocha KC: supplementation with selenium can influence nausea, fatigue, physical, renal and liver function of children and adolescents with cancer. J Med Food 18: 109-117, 2015.

92 Brodin O, Eksborg S, Wallenberg M, Asker-Hagelberg C, Larsen EH, Mohlkert D, Lenneby-Helleday C, Jacobsson H, Linder S, Misra S and Bjornstedt M: Pharmacokinetics and toxicity of sodium selenite in the treatment of patients with carcinoma in a phase I clinical trial: The SECAR Study. Nutrients 7: 4978-4994, 2015.

93 Rayman MP, Infante HG and Sargent M: Food-chain selenium and human health: spotlight on speciation. Br J Nutr 100: 238253, 2008.
Received September 6, 2017

Revised October 3, 2017

Accepted October 12, 2017 